Filipino Philosophy and Culture

\title{
Ang Pagkilos ng Pananampalataya at Utang na Loob: Si Hornedo sa Etnograpiya ng Popular na Paniniwala
}

Rhochie Avelino E. Matienzo

\begin{abstract}
The essay is a humble contribution to the commemoration of the second death anniversary of the ethnologist, philosopher, and linguist Florentino Hornedo. This aims to illustrate his analysis of "utang na loob" as culture and its relevance to faith in the context of popular belief. It further justifies that utang na loob is more than a "system of obligation" but a lifetime decision which is greater than its usual connotation. Albeit the study is just an exploration of the existing discourses, it is distinct in the manner of approach as it views this unique Filipino trait under the lens of "freedom" formulated by Hornedo.
\end{abstract}

Keywords: Hornedo, popular religiosity, utang na loob, ethnography

\section{Konteksto}

\section{Utang na loob}

$\mathrm{N}$ oong buwan ng Hunyo 2015, nagtala ang Oxford English Dictionary ng 40 salitang Filipino bilang opisyal na bahagi ng kanilang leksiko. Isa sa mga ito ay ang "utang na loob" na may pakahulugang "sense of obligation to return a favor owed to someone."1 Ang salitang "utang" ay ginagamit noon pa man simula ng nakaraang siglo sa mga bansang Timog Silangang Asya upang tukuyin ang ipinagpalibang kabayaran ng isang bagay

${ }^{1}$ Danica Salazar, "Release notes: new Filipino words," in Oxford English Dictionar (June 2015), <http://public.oed.com/the-oed-today/recent-updates-to-the-oed/previous-updates/june2015-update/release-notes-new-filipino-words $>$ (29 October 2016). Emphasis added.

(C) 2017 Rhochie Avelino E. Matienzo

https://www.kritike.org/journal/issue 21/matienzo december2017.pdf

ISSN 1908-7330

(c) BY-NC-ND 
o serbisyo. ${ }^{2}$ Maging sa kasalukuyan, mas malapit ang kulturang ito sa usaping pang-komersiyo at pananalapi. Ang salitang "loob" naman ay may mayamang pakahulugan sa wikang Filipino. Kung ito ay tumutukoy sa materyal na bagay, ito ay nangangahulugang "taliwas ng labas." Ngunit sa konteksto ng utang na loob, ang "loob" ay sumasaklaw sa higit na pisikal na depinisyon nito. Halimbawa ay ang pagsasalarawan ni Dionisio Miranda: "loob needs kapwa to be loob: its continued responding to kapwa is the condition for its own existence and authenticity as loob."3 Ayon dito, sa pamamagitan lamang ng kapwa mas tunay at malilinang ang isang kalooban. Si Albert Alejo ay nagwika rin ng kahalintulad nito: "ang loob ay isang tahanan (na kung saan) dito ang kapwa ay kasambahay." 4 Sinang-ayunan ito ni Jose de Mesa nang kanyang banggitin na "loob is a relational understanding of the person." 5 Sa mga pagsasalarawan na nabanggit, ang salitang "loob" sa utang na loob ay hindi maaaring gamitin sa material na pakahulugan nito bagkus ay higit na mauunawaan sa konteksto ng lokal na karanasan nito, partikular, sa perspektibo ng pakikipag-ugnayan ng sarili sa "kapwa." Samakatuwid, ang utang na loob ay ang pagkilala sa kagandahang loob na ipinagkaloob sa isang indibidwal. Ang pagkilala ay sa pamamagitan ng mataas na tungkuling maibalik ang kabutihang loob na natanggap. Dahil dito, ang utang na loob ay parating may pinagtutuunan: ang kapwa.

\section{Utang na loob bilang obligasyon}

Ang mataas na tungkulin sa kapwa na maibalik ang natanggap na kabutihang loob ay nagiging isang obligasyon. Ito ang nakita ni Mary Holnsteiner sa ugnayan na namamagitan sa magulang at anak: "... the children's obligation to respect and obey their parents and show their gratitude by taking care of them in old age ... continues even when the parents' duties have been largely fulfilled." 6 Ang sistematikong pagsusuri nito ay isinagawa ni Charles Kaut noong dekada '60 at ayon sa kanya, "utang na loob reflects a social system of sentiments of deep and strong affective nature and expressively symbolizes a whole configuration of reciprocal

\footnotetext{
2 Charles Kaut, "Utang Na Loob: A System of Contractual Obligation among Tagalogs," in Southwestern Journal of Anthropology 17:3 (1961), 257.

${ }^{3}$ Dionisio Miranda, Buting Pinoy: Probe Essays on Value as Filipino (Manila: Divine Word Publications, 1992), 84.

${ }^{4}$ Albert Alejo, Tao po! Tuloy!: Isang Landas ng Pag-unawa sa Loob ng Tao (Quezon City: Office of Research and Publications, Ateneo de Manila University, 1990), 111.

${ }^{5}$ Jose de Mesa, In Solidarity with the Culture: Studies in Theological Re-Rooting (Quezon City: Maryhill School of Theology, 1987), 46.

${ }^{6}$ Mary R. Holnsteiner, "Reciprocity in the Lowland Philippines," in Four Readings on Philippine Values, ed. F. Lynch and A. de Guzman (Quezon City: Ateneo de Manila University Press, 1973), 76. Emphasis added.
} 


\section{PANANAMPALATAYA AT UTANG NA LOOB}

obligations."7 Nilinaw niya na ang salitang "utang" ay may katumbas na kahulugan tulad sa isang regalo o gift. Ito ay sa kadahilanang ang obligasyon ay hindi batay sa pagsasauli ng hiniram, bagkus ay sa pagtalima sa isang kaloob. ${ }^{8}$ Bagama't mahalaga ang paglilinaw na ito, kapansin-pansin ang elemento ng obligasyon o tungkulin sa pagsusuri ni Kaut.

Tulad ng paglilinaw ni Kaut, ang inuutang sa utang na loob para kay Leonardo Mercado, ay 'di matutumbasan ng materyal na halaga. Hinalimbawa niya ang kawikaan at ang sitwasyon ng pagsagip ng isang buhay: "'Ang utang na loob ay hindi mababayaran ng salapi'... ordinary debts where stipulations are made, utang na loob makes no condition. If $X$ saves $Y^{\prime}$ 's life from drowning, $Y$ has an everlasting 'debt of volition' to $X$. $X$ does not give any terms. But out of his own will (kusang loob) $\mathrm{Y}$ tries to show his goodness to $X$ whenever he can and at his own discretion." ${ }^{9}$ Ang pagtanaw ng utang na loob, samakatuwid, ay sariling kakayahang magbalik ng kagandahang loob bilang kabayaran. Sa kabila nito, mababakas, maging sa karanasan at kultura ng marami, na ang elemento ng obligasyon ay 'di maaaring iwasan. At dahil dito, patuloy niya, "loob becomes an interior law which tells $Y$ to behave generously and amiably to $X$ even for a lifetime." 10

Maging sa kasaysayan, ang obligasyon ay makikita din bilang manipestasyon ng utang na loob. Ipinaliwanag ni Vicente Rafael na ang utang na loob ay naging kasangkapan ng pagpapalaganap ng Kristiyanismo noong mga unang daan-taon ng pananakop. Wika niya: "Caught up in what seemed like an unending stream of undecipherable words put forth in terms of reciprocal obligations, the natives 'converted', that is, availed themselves of the sacraments as a way of entering into a debt transaction with the Spaniards and their God." ${ }^{11}$ Ang pananaw na ito ay masasaksikhan din sa Pasyon and Revolution ni Reynaldo Ileto ngunit bilang kasangkapan ng paghihimagsik. Isinalarawan niya ang malalim na ugnayang nagbibigkis sa pagitan nina Felipe Salvador at ng kapatiran laban sa hukbong Amerikano noong panahon ng pananakop: "The presence of the word loob points to something other than simple economic relationship between lender and debtor, giver and receiver. In Salvador's idiom, the gift is a mode of strengthening the bonds about the loob of men. Begging and the acceptance of food, shelter and protective care create, not a subordinate-superordinate

\footnotetext{
${ }^{7}$ Kaut, “Utang Na Loob," 258. Emphasis added.

${ }^{8}$ Ibid.

9 Leonardo N. Mercado, Elements of Filipino Philosophy (Tacloban: Divine Word Publications, 1976), 65.

${ }^{10} \mathrm{Ibid}$. Emphasis added.

${ }^{11}$ Vicente Rafael, Contracting Colonialism: Translation and Christian Conversion in Tagalog Society under Early Spanish Rule (Durham and London: Duke University Press, 1993), 127. Emphasis added.
}

(C) 2017 Rhochie Avelino E. Matienzo https://www.kritike.org/journal/issue 21/matienzo december2017.pdf ISSN 1908-7330

(cc) BY-NC-ND 
relationship, but a horizontal one akin to love."12 Para kay Virgilio Enriquez, ang malalim na ugnayang ito ay nag-uugat sa katutubong kamalayan ng mga Pilipino na ang "kapwa" ay ang mismong pagkakakilanlan bilang "ako." Paliwanag niya, "kapwa is a recognition of shared identity, an inner self shared with others ... The ako (ego) and the iba-sa-akin (others) are one and the same in kapwa psychology."13

Bagama't ang paggamit sa salitang "utang na loob" ng mga ekspertong nabanggit ay nagluluklok sa mas mataas na antas ng ugnayan sa pagitan ng indibidwal at kapwa, bakas ang (tuwiran man o hindi) pagtatangi sa "obligasyon" kung saan ang isang indibidwal ay may katungkulang maibalik ang natanggap lalo pa at kung ito ay mayroong masidhing halaga, mapa-paniniwala sa Kristiyanismo man o laban sa mga pagpapalaganap nito. Ang malinaw sa mga paglalarawang ito ay ang masidhing tungkulin upang magkaroon ng tugunan (reciprocity) sa pagitan ng nagkaloob at pinagkalooban. Bagama't nilinaw ni Kaut (at iba pang mga iskolar tulad nila Mercado, ${ }^{14}$ Jocano, ${ }^{15}$ Ileto, ${ }^{16}$ at Miranda ${ }^{17}$ ) na ang utang na loob ay isang uri ng "debt of volition (that) cannot be paid by money,"18 'di maikakaila na ang transaksyon ay itinatakda pa rin ng obligasyon.

\section{Obligasyon bilang kalabisan}

Isa sa mga negatibong epekto ng pamumutawi ng obligasyon sa utang na loob ay ang pagkasira ng orihinal nitong kahulugan. Sa paliwanag ni Kaut:

Utang na loob is built on a set of firm social expectations ... failure on the part of the person of whom particular behavior is expected can generate ill, humiliation, shame, and most importantly, desire for retaliation on the part of the one expecting ... breakdown at any point threatens more than immediate relationship between

${ }^{12}$ Reynaldo Ileto, Pasyon and Revolution: Popular Movements in the Philippines, 1840-1910 (Quezon City: Ateneo de Manila University Press, 1979), 287. Emphasis added.

${ }_{13}$ Virgilio Enriquez, From Colonial to Liberation Psychology (Quezon City: University of the Philippines Press, 1992), 52-54.

${ }^{14}$ Mercado, Elements of Filipino Philosophy, 48-49, 65, 100, 191.

${ }^{15}$ F. Landa Jocano, Filipino Value System: A Cultural Definition (Quezon City: Punlad Research House, 1997), 83.

${ }^{16}$ Ileto, Pasyon and Revolution, 287. Emphasis added.

${ }^{17}$ Miranda, Buting Pinoy: Probe Essays on Value as Filipino, 185.

${ }^{18}$ Kaut, “Utang Na Loob,” 260.

(c) 2017 Rhochie Avelino E. Matienzo https://www.kritike.org/journal/issue 21/matienzo december2017.pdf

ISSN 1908-7330 


\section{PANANAMPALATAYA AT UTANG NA LOOB}

two individuals; it threatens the functioning of a whole network of relationships. ${ }^{19}$

Ang utang na loob ay maaaring magbunga ng kalabisan, katiwalian, o kawalan ng hustisya. Sa halip na tumulong at magbigay dahil sa kagandahang loob, ang iba ay "nagmamalasakit" upang sa pagdating ng panahon ay maaari din siyang "mag-obliga" ng tulong mula sa kapwa. Ayon kay Jaime Bulatao, ang senaryong ito ay nag-uugat sa nawawalang puwang na dapat sana ay nagdurugtong sa pagpapahalaga (values) at aktuwal na karanasan na nagreresulta ng "split-level" na kaisipan at pagkilos. ${ }^{20}$ Sa kahalintulad na puna, binanggit ni Felipe Landa Jocano na maaaring iba ang tono ng utang na loob sa harap ng pamilya (kinship) at iba rin naman sa harap ng publiko. ${ }^{21}$ Sa kanyang konklusyon, winika niya na "utang-na-loob which originally means 'obligation' is construed to be 'corruption'." 22 Ganito rin ang pananaw ni Vitaliano Gorospe na tumukoy sa utang na loob bilang ugat ng suliranin sa maraming aspeto sa pamayanang Pilipino:

In the Philippines utang na loob has in the past largely worked against the individual. Within the family, it has come to mean that children are expected to provide for their parents in their old age since they owe not only their life but also their entire education to their parents. The worst thing that can be said of the child who does not pay this debt of gratitude is that he is an "ingrate" (walang utang na loob) or that he is without shame (walang hiya)... Utang na loob permeates and influences all facets of the Filipino way of life-business, education, politics, morality and religion - and has been blamed for almost all the evils of Philippine society such as the "lagay" system (bribery and extortion), graft and corruption in politics and in the government, smuggling, and so forth ... utang na loob is to blame. ${ }^{23}$

Press, 1966), 2

${ }^{19}$ Ibid., 269. Emphasis added.

${ }^{20}$ Jaime Bulatao, Split-Level Christianity (Quezon City: Ateneo de Manila University

21 F. Landa Jocano, Filipino Social Organization: Traditional Kinship and Family Organization (Quezon City: Punlad Research House, 1998), 63.

${ }^{22}$ F. Landa Jocano, Issues and Challenges in Filipino Value Formation: Punlad Research Paper no. 1 (Quezon City: Punlad Research House, 1992), 8. Emphasis added.

${ }^{23}$ Vitaliano Gorospe, "Christian Renewal of Filipino Values," in Philippine Studies 14:2 (1966), 219.

(C) 2017 Rhochie Avelino E. Matienzo

https://www.kritike.org/journal/issue 21/matienzo december2017.pdf

ISSN 1908-7330

(c) $)$ BY-NC-ND 
Marami na rin ang mga nanawagan upang maibalik ang positibong katangian ng utang na loob. Kabilang na si Leonardo de Castro na nagsabi: “ang pagbabayad ng utang na loob ay hindi isang tapos na hakbang ... katulad ng pagbabayad sa utang sa bangko na tumatapos sa anumang obligasyon ... Ito ay nagsisilbing hudyat lamang ng patuloy na ugnayan na kinapapalooban ng pagpapalitan ng mga kabutihang loob." 24 Sa bersyon ni Miranda, "utang na loob therefore is no degradation or humiliation by kagandahang-loob; in fact, it is a dignification since one is given the occasion and possibility of responding in kind." 25 Sa kabila nito, bagama't malinaw ang layuning maibalik ang kagandahang loob bilang sangkap, mapapansin pa rin ang pamumutawi ng elemento ng obligasyon (materyal man o hindi) bilang isang integral na katangian ng utang na loob. Ang katanungan sa puntong ito ay: posible pa kaya ang kalayaan sa karanasang utang na loob sa ilalim ng obligasyon?

\section{Ang Popular na Paniniwala at mga Kalabisan Nito}

Ang utang na loob ayon kay Hornedo ay higit na mauunawaan sa aspeto ng popular na paniniwala. ${ }^{26}$ Sa halos lahat ng bahagi ng bansa, mayaman ang mga Pilipino pagdating sa ritwal na nag-uugat sa pinagsamang katutubo at banyagang pag-uugali. Bagaman at makailang dekada na rin ang pagkilala ng Simbahang Katoliko sa pamamaraan ng pananampalatayang ito, ${ }^{27}$ hindi pa rin ganap ang pagsang-ayon dito ng nakararami. Ayon kay Segundo Galilea, isang eksperto sa popular na paniniwala:

Popular religiosity is the religious expression of our great majorities whose faith has not been validated enough. Their evangelization has been shallow, either for lack of opportunity, or because they believe that the level of their Christian life is good enough and they are no longer interested in evangelization ... (It) has a particular affinity with the poor because it is only in this level that people's religiosity is consistent with their culture ... Therefore, popular religiosity is found at its best

\footnotetext{
${ }^{24}$ Leonardo de Castro, Ang Utang na Loob bilang Konsepto ng Etika (Quezon City: College of Social Sciences and Philosophy, University of the Philippines, 1995), 19-20; 211.

${ }^{25}$ Miranda, Buting Pinoy: Probe Essays on Value as Filipino, 185.

${ }^{26}$ Florentino Hornedo, "Notes on Filipino Religious Symbolic Action," in The Favor of the Gods (Manila: University of Santo Tomas Publishing House, 2001), 153-160.

${ }^{27}$ Paul VI, "Sacrosanctum Concilium: Constitution on the Sacred Liturygy," in The Holy See (4 December 1963) <http://www.vatican.va/archive/hist_councils/ii_vatican_council/ documents/vat-ii const 19631204 sacrosanctum-concilium en.html > § 7-13.
} 


\section{PANANAMPALATAYA AT UTANG NA LOOB}

among simple people $\ldots$ becomes paradigm in the poor classes. ${ }^{28}$

Tinutukoy na karamihan sa mga tagasunod ng popular na paniniwala ay nabibilang sa mga mananampalataya na matatagpuan sa laylayan ng lipunan na karaniwan ay hikahos at mayroong di-mataas na antas ng edukasyon. Sa kawalan ng alternatibo, sila ay mayroong mataas na pagtitiwala sa mga debosyon na masasaksihan sa mga popular na ritwal at ekspresyon ng pananampalataya. Sa karanasanag ito, sila ay "very affective and sentimental... intuitive, very concrete, and not ruled by rational logic." 29 Ang Simbahang Katoliko ay makailang ulit na sa pagpapaala-ala sa mga panganib dulot ng labis na pagtangkilik nito. ${ }^{30}$ Ayon kay Bernhard Raas, may ilang panganib na dala ang popular na paniniwala: una, "it can become more important than the liturgy;" pangalawa, it "can be one-sided and as such they can cause people to develop false priorities and values;" pangatlo, "the danger of too much subjectivism, externalism, and sentimentalism may disregard the creedal truths and liturgical practices of the Catholic Church;" pang-apat, "popular devotions can give wrong feeling of security in the presence of the living God for it may bring false hopes and at the same time degrades the perfection and supremacy of God in a level of commerce; as if faith is a matter of depositing prayers and withdrawing granted wishes;" pang-lima, it may "easily degenerate into magical or superstitious practices or even idolatry;" at panghuli, "popular rituals can be abused for other purposes like moralizing or didactic intentions." 31 Sa pag-aaral na isinagawa ni Wilfredis Jacob sa mga deboto ng Poong Itim na Nazareno ng Quiapo, kanyang napag-alaman na minsan ang mga "... devotion and the devotional prayers, specifically the novena prayer, do not provide any specific attention to the role of Christ's resurrection and glorification... there are also devotees who lead questionable moral lives, who take devotion as a means of material and temporal assistance." 32 Sa madaling sabi, ang popular na paniniwala ay nananatiling kabalintunaan sa modernong panahon ng Kristiyanismo sa bansa.

${ }^{28}$ Segundo Galilea, The Challenge of Popular Religiosity (Quezon City: Clarentians Publications, 1988), 16.

${ }^{29}$ Ibid., 17-18. Emphasis added.

${ }^{30}$ Tumutukoy na tanging ang Banal na Liturhiya lamang ang opisyal na panalangin samantalang ang "popular piety is properly optional." Paul VI, "Sacrosanctum Concilium," § 11.

${ }^{31}$ Bernhard Raas, Popular Devotions: Making Popular Religious Practices More Potent Vehicles of Spiritual Growth (Manila: Divine World Publications, 1992), 21-22.

32 Wilfredis B. Jacob, "Religious Experience in the Quiapo Black Nazarene Devotion," in Filipino Religious Psychology, ed. by Leonardo N. Mercado (Tacloban City: Divine Word University Publications, 1977), 88-89.

(C) 2017 Rhochie Avelino E. Matienzo

https://www.kritike.org/journal/issue 21/matienzo december2017.pdf

ISSN 1908-7330

(cc) BY-NC-ND 


\section{Ang Popular na Paniniwala at "Utang na Loob" ayon kay Hornedo}

Sa akdang "Philosophy in Culture and Culture in Philosophy," tinukoy ni Hornedo na ang pangunahing hamon ng pilosopiyang Filipino ay ang pagsusuri sa kulturang lokal at mga detalyeng kaakibat ng mabilis na pagbabagong-anyo ng kapaligiran ng tao. ${ }^{33}$ Isang tugon sa hamong ito ay ang kanyang akda na The Favor of the Gods (2001) na sumusuri sa mga ritwal na nakapaloob sa mga popular na paniniwala sa kanayunan at maging sa kalungsuran sa bansa. Ayon sa kanya, isa sa masidhing dahilan ng mga ritwal sa popular na paniniwala-mapa-kapistahan man o simpleng seremonya bago mangisda, magtanim, o mag-ani sa kabukiran-ay ang pagtanaw ng utang na loob sa nakatataas na kapangyarihan. Sinabi niya: "In Philippine fiestas, patrons and sponsors of the festivities have varied motives in relation to gift-giving. Some give generously with the hope of the return blessings ... But there are others who give because of affective devotion or love for the sacred other. The giving is unconditional and has no ulterior motive than a reciprocal benevolence from the sacred other." 34 Ang utang na loob sa puntong ito ay ang pag-aalay nang walang hininhitay na kapalit, bagkus isang uri ng pasasalamat sa nakakamtam na biyaya. Pinupunto ni Hornedo sa pangalawang uri na hindi tuwirang kinikilala ang materyal na aspeto ng biyaya, sa halip, ay ang kabutihang loob ng pagkakaloob ng biyaya. Sapagkat, para sa kanya, ang utang na loob ay isang "indebtedness" o pagkakautang na hindi materyal bagkus isang kabutihan loob na natanggap mula sa obheto ng pananampalataya.

The sense of indebtedness referred to does not imply obligation to pay a material debt. It is an utang na loob. The debt is not material but a good-will, a benevolence ... what is acknowledged as the primary good received is not the material token but the personal internal disposition of benevolence. The return gift is the moral donation of goodwill signified by a material token which, therefore, is not in principle expected to be identical of material value. ${ }^{35}$

\footnotetext{
${ }^{33}$ Florentino Hornedo, "Philosophy in Culture, Culture in Philosophy" Pagpapakatao and Other Essays in Contemporary Philosophy and Literature (Manila: University of Santo Tomas Publishing House, 2002), 62-63.

${ }^{34}$ Florentino Hornedo, In Favor of the Gods, 155.

35 Ibid., 154; Florentino Hornedo, Culture and Community in the Philippine Fiesta and Other Celebrations (Manila: University of Santo Tomas Publishing House, 2000), 45 (emphasis added); Florentino Hornedo, "Punas-Punas: The Filipino Idea of the Holy," in The Filipino Popular 


\section{PANANAMPALATAYA AT UTANG NA LOOB}

Bagaman at hindi ito bago sa mga pag-aaral ng mga ekspertong nabanggit sa unang bahagi, binibigyang-diin sa puntong ito na ang utang na loob sa kamalayang Pilipino ay higit pa sa isang transaksyon o obligasyong panlipunan, bagkus, ay isang uri ng malayang pagpapahayag ng pananampalataya. Ang "kalayaan" na tinutukoy dito ay tatalakayin sa susunod na bahagi.

Isang lehitimong paliwanag sa konsepto ng "obligasyon" ay ang lokus ng usapin ng utang na loob. Ang mga depinisyong nabanggit sa unang bahagi ay makikita sa lente ng historikal, sikolohikal, sosyolohikal, politikal, at antropolohikal na pananaw. Subalit, para kay Hornedo ang utang na loob sa Pilipinong karanasan, ay maaari din, at lalong higit, na nauunawan ng isang indibidwal sa kanyang personal na pakikipag-ugnayang sa Diyos na kung saan, para sa popular na paniniwala, ay sumasakop din sa kapwa.

With regards to man's relation with God, there is an ambivalence discernible in the vertical-horizontal relationship. This deity is seen both as lord and peer/ friend/ brother. In Christianity, this is expressed in the dual nature of Christ as God-man. He is lord and brother. In other religions, this appears in similar forms of incarnation. ${ }^{36}$

Dahil dito, ang "sacred other" ay hindi lamang ang Diyos bagkus tumutukoy din sa kapwa ng isang indibidwal. Ito ang konteksto ng "good will" o kagandahang loob na kinapapalooban ng utang na loob ayon kay Hornedo. Hindi ito masusukat sa halaga ng nakamtam o naipahiram, bagkus ang pagtanaw ng utang na loob ay sumasalamin sa pakikitungo ng indibidwal sa Diyos at kapwa. Ito ang nagtatangi sa panananaw ni Hornedo sa hanay ng mga naunang pagsusuri na kumikilala sa utang na loob bilang "social process" o obligasyong dapat tupdin kung nais ng indibidwal na maging katanggap-tanggap sa mata ng lipunan. Ang balangkas na ito ni Hornedo ay nagmumula sa Pilipinong kaisipan na "pangkabuuan." Dito walang paghahati na umiirial sa pagitan ng obheto at suhetong kalagayan tulad ng nakagawian sa Kanluraning ontolohiya. Ito ang tinukoy ng konsepto ng "sakop" ni Mercado, "kapwa" ni Enriquez, ang 'di maiiwasang pagtugon

Devotions: The Interior Dialogue Between Traditional Religion and Christianity, ed., Leonardo N. Mercado (Manila: Logos Publications, Inc., 2000), 50-51.

${ }^{36}$ Ibid., 154. Emphasis added.

(C) 2017 Rhochie Avelino E. Matienzo

https://www.kritike.org/journal/issue 21/matienzo december2017.pdf

ISSN 1908-7330

(c) BY-NC-ND 
ng "loob" sa kapwa nina Miranda ${ }^{37}$ at Alejo," ${ }^{38}$ maging ang "kagandahang loob" ni De Castro ${ }^{39}$ at De Mesa. ${ }^{40}$

Kung sususugin ang balangkas na ito, mauunawaan na ang mga kalabisan sa pagganap ng popular na paniniwala na madalas punahin ng mga eksperto ay isa lamang pagpapahayag ng marubdob na pagtugon ng utang na loob sa obheto ng kanilang pinanampalatayaanan. Samakatuwid, ang pagpapahayag ng popular na paniniwala ay sukdulan sa karanasang utang na loob. Ito ay konkretong naipamamalas sa paggunita ng mga maraming kapistahan sa bansa katulad ng sa Itim na Nazareno ng Quiapo sa Maynila, Santo Niño sa Cebu, Birhen ng Peñafrancia sa Naga, Ina ng Piat ng Tuguegarao, at iba pa; na kung saan ang paghawak at pagpunas ng tuwalita sa karosa o sa imaheng-ukit ay nangangahulugang ganap na pagkakahawak kay Hesus o sa Birheng Maria. ${ }^{41}$

Sa mga okasyong ito, makikita din ang pagbabayanihan ng mga tao na hindi magkakakilala o kabilang sa isang antas ng lipunan, bagkus isang bukluran na may iisang mithiin. Para kanino ang kagandahang asal na ipinakikita ay hindi tuwirang nakatuon sa kapwa ngunit sa kagandahang loob sa kanila'y ipinagkaloob ng kanilang pinaniniwalaan (personal na Diyos). At dahil dito, walang lohikal na katuwiran ang makakaunawa hangga't hindi nararanasan ang dinamikong galaw ng pananampalataya ayon kay Hornedo.

Matatandaan na ang utang na loob bilang isang "contractual reciprocal obligation" (Kaut, Jocano, at Gorospe) ay maaaring magpuwang ng kalabisan, kawalan ng hustisya, at katiwalian. Ngunit ang balangkas na pangkabuuan ni Hornedo ay hindi nagpapahintulot ng anumang bahid ng pag-abuso sapagkat ang ugnayang pantao (horizontal) ay walang pinagkaiba sa ugnayang pang-Diyos (vertical). Walang sinuman ang magnanais na gawan ng kasamaan ang isang pinipintuho lalo pa't ito ay ang obheto ng pananampalataya. Ito ang dahilan na sa kabila ng sakitan o kamatayan man sa pagganap ng ritwal, walang demandahan o asultong naitatala na tuwirang may kinalaman sa pagdedebosyon. Ito ay sapagkat ang pakikitungo sa Diyos

${ }^{37}$ Miranda, Buting Pinoy: Probe Essays on Value as Filipino, 84.

38 Alejo, Tao Po! Tuloy!, 111.

${ }^{39}$ De Castro, Ang Utang na Loob bilang Konsepto ng Etika, 211.

${ }^{40}$ De Mesa, In Solidarity with Culture, 35.

${ }^{41}$ Hornedo, "Punas-punas: The Idea of the Holy," 50. Isinalarawan ni Hornedo ang mga dotobong Ivatan sa isla ng Batanes tuwing Mahal na Araw pagkatapos ng prusisyon: "start cutting with a nail clipper the hair of the Nazareno ... they can (even) cut with scissors parts of the robe of the statues." Ito, para sa kanya, ay hindi isang uri ng kalapastanganan; bagkus, itoy's mahalagang bahagi ng kanilang paniniwala. Patuloy pa niya, "the basic principle is that the holy is transmissible and things can become sacred by association, by touch. And punas-punas, I think, is like the handkerchief with which you touch something holy becomes holy too." Ibid., 51. 


\section{PANANAMPALATAYA AT UTANG NA LOOB}

ay pakikitungo din sa kapwa. Ito ang utang na loob na para kay Hornedo ay isang:

... social gift-giving rooted in the dual aspect of the divine as lord and friend. While to God's lordship, any offering is to be regarded as tribute-giving of vassal to lord, to his humanized reality, gift-giving as from friend to friend is the paradigm. ${ }^{42}$

Ang kawalang ng dikotomiya sa pagitan ng Diyos at kapwa ay nakahayag sa relasyong utang na loob. Dito ang ugnayan ay walang inaasahang kapalit o obligasyong magbigay. Sa halip, tanging kagandahang loob at kabutihan lamang na masasaksihan sa kanilang pagganap ng popular na paniniwala.

\section{Ang kabalintunaan sa popular na paniniwala at ang kalayaan sa utang na loob}

Ang kawalan ng malinaw at tiyak na dikotomiya sa pagitan ng Diyos at kapwa dulot ng "pananaw na pangkabuuan" ay nagreresulta sa masalimuot na pagtingin mula sa lohikang pangangatwiran. Ngunit ang kabalintunaan nito ay isang "paradox" na maituturing: di-maunawaan ngunit makabuluhan. Sa popular na paniniwala, ang indibidwal na mananampalataya ay nag-aalay ng higit pa sa kanyang kinikita, oras, at minsan, ay ang kahandaang ibuwis ang kanyang buhay. Ito ay hatid ng masidhing pagtanaw ng utang na loob.

Para kay Hornedo, ang tunay na batayan ng pagiging relihiyoso ay ang pagkilala sa utang na loob, at gayundin naman, ang tunay mananampalataya ay ang pagtanaw ng utang na loob. Ang pagpapasalamat sa utang na ito ay nararanasang lubos sa popular na paniniwala kung saan walang hinihintay na kapalit. Hindi ito madaling maintindihan sa lohikal na pag-iisip sapagkat ang kawalan ng katuwiran ay ang siyang ang nagbibigay kahulugan. Ito'y, para sa mananampalataya, ang kapasyahang 'di maaabot ng pag-iisip. Maging ang salitang "pananampalataya," na may salitang-ugat na "sampalataya," ay maaaring tingnan sa kilos ng "pagtaya," Pagtaya na walang kasiguraduhang mapapantayan at 'di maaaring tumbasan ng

${ }^{42}$ Hornedo, "Punas-Punas: The Filipino Idea of the Holy," 155. Emphasis added.

(C) 2017 Rhochie Avelino E. Matienzo

https://www.kritike.org/journal/issue 21/matienzo december2017.pdf

ISSN 1908-7330

(c) BY-NC-ND 
anumang kabayaran ang "utang" na ipinagkaloob mula sa pananampalataya. ${ }^{43}$

Hindi ito nangangahulugan ng pagka-alipin o pagpapasailalim sa isang sistemang relihiyon, bagkus isang kalayaan mula sa dikta ng lipunang nakagawian nito. Halimbawa na nga dito ay ang hindi pagsunod sa mga atas ng simbahan upang magpuri sa kaparaanang siya lamang ang nakakaunawa. Ito hindi kaaya-aya sa marami ngunit wagas na nagpagpapahayag nito. Kung bakit marami ang nakayapak at nagsusuot ng saya kagaya ng sa imahe o pagsasayaw sa kainitan ng araw ay paraan ng pagpapahayag ng utang na loob bilang walang hanggang pasasalamat sa nakamit na kagalingan ng kalusugan, pagsumpong sa nawawalang mahal sa buhay, 'di inaasahang biyaya, at iba pa. Ang indibidwal sa pagkakataong ito ay 'di maituturing na panatiko sapagkat siya ay may sariling pagpapasya at naghahayag sa paraang nais niya. Kalayaang walang kinatatakutan na paghuhusga ng lipunan at mga institusyon nito. Kung kaya't para kay Hornedo, ang utang na loob ay isang pagpapahayag ng kalayaan at hindi obligasyon:

The Filipino notion of utang na loob cannot be regarded as is generally done, as "debt inside." It is a debt of goodwill, that is, what is owed is goodwill and it invites reciprocation with goodwill. This reciprocation is to an appeal rather than to demand. It is an appeal to freedom rather than obligation. ${ }^{4}$

Kung ang utang na loob ay mananatili sa aspeto ng obligasyon (Kaut), ito ay isa lamang "never-ending involving reciprocal gift giving and a constantly alternating state of indebtedness." 45 Dito, walang kalayaan na mararanasan bagkus ay isang kumunoy ng pagpapalitan ng pabor na maaaring maging pabigat sa ugnayan at kadalasan ay ugat ng korupsiyon. Ipinaliwanag ni Hornedo na sa konteksto ng popular na paniniwala, ang

${ }^{43}$ Ang utang na loob bilang kagandahang loob sa lente ng pananampalataya ay makikita rin sa paliwanag ni Jose De Mesa. Ayon sa kanya, ang utang na loob ay isang uri ng pagtugon ng tao sa pagkakaloob ng Diyos ng kaligtasan sa sanlibutan: "Faith as utang na loob is an appropriate response to God's eminent kagandahang-loob ... to use kagandahang-loob to describe God's salvific activity for our sake is to emphasize that God in relating with us is always kagandahang-loob for us. He is wholly intent on our salvation, wholeness and wellbeing." De Mesa, In Solidarity with Culture, 38; 50. Bagama't may pagkakahalintulad sa konklusyon ni Hornedo, magkaiba ang dalawa sa pamamaraan ng pagtanto. Ang kay De Mesa ay teolohiya samantalang ang kay Hornedo ay sa pamamagitan ng etnolohiya at pilosopiya ng relihiyon. Bukod dito, naisalarawan ni Hornedo ang kawalan ng katuwiran sa ilang mga popular na ritwal samantalang ang kay De Mesa ay nakatuon sa doktrina at katuruan ng Katolisismo na may pagaalinlangan sa pamamaraan ng pagsampalataya sa popular na paniniwala.

${ }^{44}$ Hornedo, "Punas-Punas: The Filipino Idea of the Holy," 155.

${ }^{45}$ Kaut, “Utang Na Loob,” 260.

(c) 2017 Rhochie Avelino E. Matienzo

https://www.kritike.org/journal/issue 21/matienzo december2017.pdf

ISSN 1908-7330

(cc) BY-NC-ND 


\section{PANANAMPALATAYA AT UTANG NA LOOB}

utang na loob na nakabatay sa obligasyon ay huwad na pagtangi sa Diyos at kapwa. Ito ay nagaganap kung ang pagtingin sa "sacred other" ng indibidwal ay kapantay lamang ng antas ng isang pisikal na bagay. Sinabi niya:

There is ever present threat of magic in which acts of gift giving on this plane become regarded as manipulation of the sacred other with the hope that every act of giftoffering obliges the Other to act automatically magically. It follows the formula "I do this to obtain this, and things happen as I wish them to." This springs from an I-It view of religious relationship, whereas it should remain I-Thou since the Other is not object but Subject. It is from this criterion that authentic religion is judged. ${ }^{46}$

Sa pangkaraniwan, nananalangin ng marubdob ang isang tao, dahilan upang siya ay magkaroon ng "karapatan" at mag-obliga sa Diyos ng biyaya. Sa sitwasyong ito, ang obheto ng kanyang dalangin ay katulad ng isang refrigerator na bumubukal ng pagkain o kaya naman ay ang "bangko" na tinutukoy ni Paulo Freire kung saan dineposito/binabawi ang kaalaman. ${ }^{47}$ Ito ang dahilan kung bakit minsan ang isang deboto (gayun din ang indibidwal sa pakikitungo sa kapwa) ay naghihinanakit kapag hindi nakamit ang hinihiling. Ito ay sa kadahilanang ang utang na loob ay nasa pamantayan lamang ng "obligasyon." Hinalimbawa ni Hornedo ang pagbibigayan ng handog o regalo:

The folk understanding of duty in the face of blessings received is gift giving ... involves an unspoken custom which says that the receiver of a gift must, in appropriate time, be a gift-giver. The cultural perspective, however, does not allow gifts to be regarded as obligating reciprocation. It is seen as a free, and therefore, noobligatory action. But in the cultural context, everyone is expected to perform such free act as gesture of good will. And while it is true that custom can get perverted as when spontaneity in gift-giving degenerates into a tradition of obligatory reciprocation every time one receives a gift, this degeneration is a decadence of the custom and is below the cultural ideal." ${ }^{4}$

\footnotetext{
${ }^{46}$ Hornedo, The Favor of the Gods, 155. Emphasis added.

47 Paulo Freire, "The 'Banking' Concept of Education," in Ways of Reading, ed. by, D. Bartholomae and A. Petrosky (Boston: Bedford-St. Martin's, 2008), 247.

${ }^{48}$ Hornedo, The Favor of the Gods, 154-155.

(c) 2017 Rhochie Avelino E. Matienzo

https://www.kritike.org/journal/issue 21/matienzo december2017.pdf

ISSN 1908-7330

(c) BY-NC-ND
} 
Tuloy, marami ang umiiwas na mapagkakalooban ng tulong mula sa kapwa upang pagdating na panahon ay hindi malagay sa 'di kaaya-ayang sitwasyon hatid ng obligasyon. Subalit, ito ang sumisira sa kultura ng utang na loob na dapat sana ay taimtim ang layuning magkakaloob at mapagkalooban. Ang pagkakaloob ay malaya sa obligasyong sapilitang nagpapawalang saysay sa kabutihang loob na nakapaloob dito. Samakatuwid, ang "obligasyon" ay taliwas sa tunay na halaga ng "utang na loob." Sa babala ni Hornedo, "The line of distinction is thin but real," sapagkat para sa kanya, "gift-giving is that free gift-giving that, by the fact of its gratuity, expects no return - an attitude that remains intact even when the same gift-giver in his turn graciously receives a gift from the one to whom he had previously given a gift." 49

\section{Konklusyon}

Ang akdang ito ay isang pagpapayabong sa mga naunang pakahulugan ng "utang na loob." Ayon, sa etnolohiya at pilosopiyang pagaaral ni Hornedo, maaaring idagdag ang mga sumusunod na tuklas: una, ang utang na loob ay higit pa sa obligasyong panlipunan lalo na kung sisipatin sa popular na paniniwala. Sa kotekstong ito, ang kulturang ito ay bunga ng isang malayang pagpapasya na nagmumula sa indibidwal na kalooban. Pangalawa, mayroong paradoksikong katangian ang utang na loob. Para sa karamihan, ang pagtaya sa walang katiyakan ay malabong usapan, malayo sa katotohanan, at madalas ay "kahibangan" lamang. Ngunit sa isang mananampalataya, ito ay malinaw at puno ng kabuluhan sapagkat tukoy niya na kailan man ay hindi niya maaaring tumbasan ang kabutihang ipinagkaloob sa kanya ng Diyos (maging ng kanyang kapwa). Ito ang dahilan ng sari't saring ritwal ng mga popular na paniniwala laganap sa iba't ibang bahagi ng bansa. Dito ay patuloy sila sa pagtupad ng panghabang-buhay na panata kapalit man nito ay diskriminasyon, pagkalugi, at kung minsan pa ay pagkasawi. Ikatlo, ang pagganap ng utang loob sa konteksto ng popular na paniniwala ay may kakaibang katuparang taglay para sa mananampalataya. Mula sa kanila ay kadalasang maririnig ang katagang "walang hanggang pasasalamat." Para kay Hornedo, ito ay sa dahilang, "'gratitude' (grata) indicates the pleasure at receiving benefice." 50 Sa pagganap ng utang na loob, mayroong kasiyahan at katuparang nararanasan na siyang nagpapanatili ng mainit at marubdob na pananampalataya habang ginaganap ang mga popular na ritwal. Samakatuwid, ang utang na loob sa konteksto ng popular

\footnotetext{
${ }^{49} \mathrm{Ibid}$.

${ }^{50}$ Hornedo, The Favor of the Gods, 156.
} 


\section{PANANAMPALATAYA AT UTANG NA LOOB}

na paniniwala ay nararanasan hindi sa lebel ng isang obligasyon lamang, bagkus ay sa pinakamataas na antas ng kabutihang loob nagmumula sa ng kanyang pinananampalatayanan.

Department of Philosophy, University of Santo Tomas, Philippines

\section{References}

Alejo, Albert, Tao po! Tuloy!: Isang Landas ng Pag-unawa sa Loob ng Tao (Quezon City: Office of Research and Publications, Ateneo de Manila University, 1990).

Bulatao, Jaime, Split-Level Christianity (Quezon City: Ateneo de Manila University Press, 1966).

De Castro, Leonardo, Ang Utang na Loob bilang Konsepto ng Etika (Quezon City: College of Social Sciences and Philosophy, University of the Philippines, 1995).

De Mesa, Jose, In Solidarity with the Culture: Studies in Theological Re-Rooting (Quezon City: Maryhill School of Theology, 1987).

Enriquez, Virgilio, From Colonial to Liberation Psychology (Quezon City: University of the Philippines Press, 1992).

Freire, Paulo, "The 'Banking' Concept of Education," in Ways of Reading, ed. by, D. Bartholomae and A. Petrosky (Boston: Bedford-St. Martin's, 2008).

Galilea, Segunda, The Challenge of Popular Religiosity (Quezon City: Clarentians Publications, 1988).

Gorospe, Vitaliano, "Christian Renewal of Filipino Values," in Philippine Studies 14:2 (1966).

Holnsteiner, Mary R., "Reciprocity in the Lowland Philippines," in Four Readings on Philippine Values, ed. F. Lynch and A. de Guzman (Quezon City: Ateneo de Manila University Press, 1973).

Hornedo, Florentino, Culture and Community in the Philippine Fiesta and Other Celebrations (Manila: University of Santo Tomas Publishing House, 2000).

"Notes on Filipino Religious Symbolic Action," in The Favor of the Gods (Manila: University of Santo Tomas Publishing House, 2001).

"Philosophy in Culture, Culture in Philosophy" Pagpapakatao and

Other Essays in Contemporary Philosophy and Literature (Manila: University of Santo Tomas Publishing House, 2002).

"Punas-Punas: The Filipino Idea of the Holy," in The Filipino Popular Devotions: The Interior Dialogue Between Traditional Religion and Christianity, ed., Leonardo N. Mercado (Manila: Logos Publications, Inc., 2000).

(C) 2017 Rhochie Avelino E. Matienzo

https://www.kritike.org/journal/issue 21/matienzo december2017.pdf

ISSN 1908-7330

(cc) BY-NC-ND 
Ileto, Reynaldo, Pasyon and Revolution: Popular Movements in the Philippines, 1840-1910 (Quezon City: Ateneo de Manila University Press, 1979).

Jacob, Wilfredis, "Religious Experience in the Quiapo Black Nazarene Devotion," in Filipino Religious Psychology, ed. by Leonardo N. Mercado (Tacloban City: Divine Word University Publications, 1977)

Jocano, F. Landa, Filipino Social Organization: Traditional Kinship and Family Organization (Quezon City: Punlad Research House, 1998). Filipino Value System: A Cultural Definition (Quezon City: Punlad Research House, 1997). Issues and Challenges in Filipino Value Formation: Punlad Research Paper no. 1 (Quezon City: Punlad Research House, 1992).

Kaut, Charles, “Utang Na Loob: A System of Contractual Obligation among Tagalogs," in Southwestern Journal of Anthropology 17:3 (1961).

Mercado, Leonardo N., Elements of Filipino Philosophy (Tacloban: Divine Word Publications, 1976).

Miranda, Dionisio, Buting Pinoy: Probe Essays on Value as Filipino (Manila: Divine Word Publications, 1992).

Paul VI, "Sacrosanctum Concilium: Constitution on the Sacred Liturygy," in The Holy See (4 December 1963) <http://www.vatican.va/archive/ hist councils/ii vatican council/documents/vatii const 19631204 sacrosanctum-concilium en.html $>$.

Raas, Bernhard, Popular Devotions: Making Popular Religious Practices More Potent Vehicles of Spiritual Growth (Manila: Divine World Publications, 1992)

Rafael, Vicente, Contracting Colonialism: Translation and Christian Conversion in Tagalog Society under Early Spanish Rule (Durham and London: Duke University Press, 1993)

Salazar, Danica, "Release notes: new Filipino words," in Oxford English Dictionar (June 2015), <http://public.oed.com/the-oed-today/recentupdates-to-the-oed/previous-updates/june-2015-update/releasenotes-new-filipino-words $>$ (29 October 2016). 